\title{
THE NATIONAL FISCAL ADMINISTRATION - CHALLENGES AND EXPECTATIONS
}

\author{
KRZYSZTOF TESZNER ${ }^{l}$
}

\begin{abstract}
The organizational and legal solutions introduced in Poland in 2017, aimed at improving state revenue collection, resulted in establishing the National Fiscal Administration. The adopted solutions have introduced a change in the functioning of the tax administration and a strengthening of its supervision. In the procedural dimension, the administration has been equipped with new tools of control of liable entities. A challenge faced by the National Fiscal Administration is an improved collection of revenue and duties through the introduction of effective audits, prosecution of the tax crime, and undertaking police actions. The expectations that honest taxpayers direct at the administration are a friendly approach to taxpaying entities and assistance and support in their fulfillment of tax obligations. In the Author's opinion, the adopted solutions introduce unequal treatment of liable entities. The assistance and support tool offered to them fails to mitigate the newly-introduced repressive legal instruments. Doubtlessly, when introducing legal solutions in the public interest, the individual interest of taxpayers and entrepreneurs should be taken into consideration to a greater extent.
\end{abstract}

\section{Keywords}

Tax administration; tax bodies; tax due; public interest

\section{JEL Classification: E62, K34, K40}

\footnotetext{
1 Assistant professor at Department of Administrative Law, Faculty of Law, University of Bialystok, Poland; The Author specializes in tax law and administrative law. He is the author of 2 books, and the coauthor of 4 books. He has published more than 120 articles and conference papers. He is a member of Information and Organization Centre for the Research on the Public Finances and Tax Law in the Countries of Central and Eastern Europe. Contact email: k.teszner@uwb.edu.pl
} 


\section{Introduction}

Ensuring the reliability and effectiveness of public institutions resulting from the preamble to the Constitution of Poland has become a principle and a real challenge for employers. This is particularly important in the cases when the legislator, recognizing the constitutional obligation to bear the burdens and public benefits, is guided by the need to protect values such as national financial security. In the area regulated by public law, including administrative law and tax law, public purposes and other values, such as the public interest, public good, or public matters exercised within the limits of the law, must be indicated. The concept of public interest is always dependent on the system of values adopted by the legislator and has a strong axiological basis. A public interest derived from public good has remained among the aims of administration activities, the administration being bound by law in this respect (Boć, 2010: 39).

Hence, acting in the public interest is the main purpose of administration and also its important feature (Zimmermann, 2016: 35). The question arises, however, as to how to achieve reliability and effectiveness of public administration when concentrating its activity on meeting the public interest to the largest possible degree. It seems that in the long-term perspective the aim may be achieved by, first of all, optimizing the administrative structure and, secondly, through adequate separation of tasks among public administration bodies, i.e. in a way that would offset their dysfunction and preclude overlap of competence. Lastly, it becomes important to introduce transparent audit and legal procedures to be applied by public administration.

The aforementioned areas of legal regulations seem particularly important as far as the rise in organized tax crime and the need for tax administration to disclose and prosecute it are concerned. These factors may undoubtedly be the reason for the organizational changes introduced into the tax administration itself, which should act in the public interest, belonging to society at large. The beneficiary of the advantages connected with the closing of loopholes in the tax system and elimination of tax evasion or fraudulent tax returns is society at large. This aim seems possible to attain provided that flexible screening procedures of taxpayers' compliance are accompanied by specific instruments of audit focused on detection and prosecution of tax crime and violations, in addition to Authoritative possibilities for tax administration bodies to make an impact on entities liable to pay tax.

Since 1 March 2017, the National Fiscal Administration has been in operation in Poland. The purpose of its establishment results from the preamble of the act on its establishment, the statutory definition, and the tasks assigned to the administration in question. The aim of this contribution is to present, analyze, and assess the legal solutions regulating the organization and functioning of the National Fiscal 
Administration in the context of the challenges it faces and the expectations of the liable entities. From the very start of the deliberations, an assumption should be made that due to the fact that tax administration is expected to act in the public interest, it must not ignore or be damaging to an individual's interest (Zimmermann, 2016: 39). It is important to introduce such mechanisms of tax administration functioning that would consider public interest together with an individual's interest, retaining possibly relative stability.

\section{Challenges Faced by National Fiscal Administration}

\subsection{General Remarks}

In order to establish the National Fiscal Administration, two acts had to be adopted: the Act of 16 November 2016 on the National Fiscal Administration and the introductory act, i.e. the Act of 16 November 2016 Regulations implementing the Act on the National Fiscal Administration, which introduced changes to over 150 provisions of other acts. The indicated purposes of the introduced changes were: to reduce the scale of tax fraud; to increase the effectiveness of revenue and duty collection; to improve the level of the voluntary character of compliance with fiscal obligations; to ensure a high level of client service; to reduce the operating costs of tax administration, in comparison with the level of the received entitlements; and to develop professional staff. The existing tax administration was considered unable to meet the challenges, due to its fragmented organizational structure, different operating standards, lack of uniform procedures, dispersion and overlap of competence, the competitive character of the undertaken actions, or the lack of a clearly defined career path.

\subsection{Decisive Factors for the Modernization of the Tax Administration in Poland}

In the last 19 years, i.e. since the Tax Ordinance Act of 29 August 1997 came into force on 1 January 1998 (referred to as TOA), no fundamental or systemic reform of the organization of tax administration was made, one that would cover all its segments (Teszner, 2014: 690). The administration, subject to the Minister of Finance until the end of February 2017, was functioning within the framework of three independent organizational divisions:

- Tax Administration (16 tax chambers and 400 tax offices);

- Customs (16 customs offices, 45 customs offices together with 141 customs branches); 
- Fiscal Audit (16 fiscal audit offices).

Thus, the territorial structure of the tax administration was dispersed, while some of the statutory tasks connected with tax and duty collection overlapped. Moreover, there were legal acts in force that regulated the issues of audits carried out by fiscal audit bodies, tax authorities, and customs authorities. In practice, this state of affairs resulted in the taxpayers being subject to different audit procedures. Another aspect that should be mentioned is the lack of uniform supervision. Despite the fact that the whole administration was formally under the Minister of Finance, it was de facto exercised independently by heads of the respective organizational divisions in units of the Ministry of Finance.

It must be assumed that the failure to undertake conceptual work on a comprehensive reform of the tax administration was mainly a result of a lack of political will. A visible change of the tax administration in Poland, on the other hand, was evident in the area of its functions and tasks. This was largely caused by the legislator gradually moving away from the method of the fulfillment of tax obligations based on the amounts established by way of decision and basing the current tax system on taxpayers themselves calculating the amount of the tax due, accompanied by the relevant supporting data required by the tax authorities. The activity of the tax authorities was targeted more specifically at performing checks, tax audits, and verification of the amount of due tax declared by the taxpayer during tax proceedings, as well as detection and taxation of undisclosed income.

The reduced tasks related to the amounts of tax due together with the increased intensity of audits and enforcement activities have had an impact on the increased number of tasks connected with entrepreneur services. The economic reality and the mutual expectations of the tax administration and the applicants, whose scale of activity is increasing within the globalized economy, have changed. Functionally, the tax administration has to some extent received the designation of servicing administration, or even infrastructure administration, as it is currently managing an ICT infrastructure, offering the taxpayers certain products and e-services (Niewiadomski, 2010: 21). At the same time, adapting the organizational units that comprise the tax administration to taking effective actions eliminating aggressive tax optimization in the cross-border aspect has become a real challenge. Tax administration should be capable of taking intense actions aimed at administrative cooperation in the area of taxes and duties, such as exchange of information and mutual assistance in the area of tax evasion and carrying out joint audits, including ones in the presence of tax administration officials from another country. 


\subsection{National Fiscal Administration - Organizational Aspects in Context of the Assigned Tasks}

The aforementioned factors had an undeniable impact on the establishment of the National Fiscal Administration on 1 March 2016, in place of the existing Tax Administration, Customs Service, and Fiscal Audit. The modernization of the tax administration in Poland mainly consisted in the consolidation of the customs and audit divisions, while retaining the existing tax administration units (tax offices and tax administration chambers) virtually unchanged as to their form and numbers. Its effect was the abolition, on the basis of Art. 160 of the NFA introductory act, of: 1) Fiscal Audit authorities conducting audit proceedings, i.e. General Inspectorate of Fiscal Control (GIKS) and the directors of Fiscal Audit offices, 2) the directors of tax chambers and heads of customs offices - Authorized to perform customs audits and proceedings and exercise tax control on the basis of TOA regulations. Within the framework of the National Fiscal Administration, Customs and Fiscal Audit was established, a uniform and uniformed formation consisting solely of officers. Its main task is to perform new customs and fiscal audits. Hence, the consolidation of the existing customs administration and Fiscal Audit has not only led to a resolution of its bodies, but also to an elimination of certain audit procedures.

Art. 11 of the NFA Act lists the newly established NFA bodies. These are: 1) the Minister of Finance, 2) the Head of the National Fiscal Administration, 3) the Director of the National Tax Information, 4) the director of the tax administration chamber, 5) the head of the tax office, and 6) the head of the customs and tax office. The consolidated fiscal administration is subject to the Minister of Finance. Formal and direct supervision of NFA bodies is exercised by the Head of the National Fiscal Administration, appointed by and subject to the Minister of Finance. Moreover, a newly established body, the director of the National Tax Information, was Authorized to issue, throughout Poland, individual interpretations of tax law provisions, on request of the interested entities. The consolidation of the tax administration was carried out simultaneously in two areas, i.e.:

1) at the central level, within the framework of departments in the Ministry of Finance,

2) at regional and local levels: tax chambers and tax offices, fiscal audit offices, customs chambers, and offices - into tax administration chambers as well as tax offices and customs and tax offices.

In the opinion of the legislator, such a model of the National Fiscal Administration will ensure effective tax collection, improve taxpayer service as far as their tax and customs obligations are concerned, ensure efficient administrative execution of claims, reduce the tax gap, and improve the effectiveness and efficiency of 
recovery of claims and taxpayers' audits. Other aims of the introduction of a new organizational model of tax administration is to ensure better communication and cooperation between tax administration bodies, improve the system that provides national financial security and protect the customs border of eastern Poland, and improve the image of the tax administration (National Fiscal Administration Act substantiation document, 2017).

The legislator's belief is that consolidation, even centralization, of organizational and supervisory processes within the framework of a tax administration will bring the expected results. However, as is rightly emphasized, the employer's conviction as to the achievement of these effects is intuition-based wishful thinking as the draft bill considered in the parliament was the deputies', not the government's, it, therefore, did not require preparation and presentation of analyses necessary to assess the regulation's consequences (Gajewski, Nowak-Far, 2016: 8). It is obvious that work on a legislation of such magnitude cannot be performed hastily and remain without consequences in terms of adopting inappropriate solutions, incompatible with other regulations, including the TOA. Introducing serious systemic and organizational solutions to the tax administration requires conceptual work, not to mention a wider discussion on the proposed solutions with experts' participation. It appears that the developments of the administrative and tax law doctrines, whose representatives indicated the deficiencies of the fiscal administration in numerous studies, were not made use of (Kosikowski, 2011: 345-346; Smoleń, 2009: 145146; Teszner, 2012: 408-409; Kulicki, 2014: 209-219). At the same time as the conviction as to the achievement of the expected results was being expressed, no in-depth diagnosis of the existing state of the tax administration was performed and no factors determining the weakness and low effectiveness of the individual segments of the fiscal administration were indicated; in addition, no relevant calculations, including those concerning the costs and benefits of the implemented solutions, were presented. This state of affairs may undermine the viability of the consolidation of the financial audit and the Customs Service in a situation when, in the opinion of the management of the Ministry of Finance, the efficiency of these units was constantly improving, whereas the performed audits brought results in the form of increased state revenues.

The basic regulations of the National Fiscal Administration Act were prefaced with a preamble, which emphasizes both the values that guided the legislator when drafting the law and the objectives to be achieved. These can be described as the challenges brought about by a consolidated tax administration. First of all, a reference to one of the traditional tax rules, one that is constitutionally empowered, i.e. the principle of the generality of taxation (Constitution of Poland, Art. 84), should be noted. This principle implies that the obligation to bear the burdens and 
public benefits, including taxes, as specified in the law, is shared by all entities. Indirectly, the principle is connected with the principle of equality before the law (Constitution of Poland, Art. 32/1) and the principle of tax justice (Kosikowski, 2004: 201). According to the doctrine, it can be assumed that tax burdens should be distributed fairly, therefore tax law should be made according to the principle of the norm of justice (Gomułowicz, 2005: 149-151). The generality of taxation as an expression of social justice has been repeatedly emphasized in the jurisprudence of the Constitutional Tribunal (K.28/98, K.12/94). One of its aspects is not only equal treatment of entities as far as taxation is concerned but also effective tax collection and detection of tax offenses (Oniszczuk, 2001: 149-150). Breach of the principles of justice on the part of liable entities may lead to tax avoidance, the commitment of fraud or tax offenses, and evasion of tax law. In consequence, this would mean a deviation from the constitutional principle of the generality of taxation.

The preamble indicates that when drafting the National Fiscal Administration Act, the legislator was guided by the concern for the "financial security of the Republic of Poland"; it also took into consideration the protection of "safety of the whole customs territory of the European Union". These terms are not explained for the needs of the Act; hence, they do not have the normative effect. They are used again in Art. 1/2 of the Act, defining the National Fiscal Administration, which is described as a specialized governmental administration performing tasks in the area of collection of revenue derived from taxes, customs duties, charges, and non-tax state revenues, protection of the interest of the Treasury, and protection of the whole customs territory of the European Union (Teszner, 2018: 11). The Tax Administration, as a special administration, undertakes actions aimed at the protection of the values indicated by the legislator as important. The fact that the administration acts in the financial public interest, understood as the interest of the public finances, is undeniable. Ensuring financial stability and reducing the tax gap were indicated as the very objective of the modernization of the fiscal administration.

The general scope of the National Fiscal Administration thus defined is detailed in Art. 2 of the Act, which contains a detailed catalog of 20 tasks of the NFA. The catalog has two major disadvantages. Firstly, it is not a closed catalog, which may be understandable due to the objective difficulties inherent in an attempt at a clear and exhaustive inclusion of all tasks realized by the NFA in a single normative act. Secondly, when establishing the National Fiscal Administration, the tasks thitherto realized by the consolidated divisions of the administration organizationally subject to the Minister of Finance were simply transferred to the new act, without their necessary review and verification. This is a serious allegation. It has been a common practice in the last several years to constantly increase the number of tasks assigned to the bodies operating within the framework of the existing 
administration, often without an increase in the overlays necessary for their implementation. For example, the range of tasks performed by the fiscal audit in the final period of its operation was increased to 17. Definitely, only correctly defining the implementation tasks makes it possible to establish an administrative structure that would be necessary for their implementation. This is essential especially as far as the newly-established organizational structure of the administration is concerned (NFA) and is not a common course of action, particularly in the context of undertaking consolidative actions.

\subsection{New Powers and Competencies of National Fiscal Administration Bodies}

In addition to identifying the general tasks of the National Fiscal Administration in Art. 2 of the Act, specific provisions of the Act divide the tasks among the individual bodies of the administration. Hence, the tasks are indicated in the following manner: those assigned to the Director of the National Fiscal Administration in Art. 14; those assigned to the Director of the National Tax Information - in Art. 22; those assigned to the director of the tax administration chamber - in Art. 25; those assigned to the head of the tax office - in Art. 28; those assigned to the head of the customs and tax office - in Art. 33 of the Act. The framework and purpose of this contribution do not allow to discuss all the tasks of the tax administration bodies. It is unclear why typical competences of the bodies, such as, for instance, tax and customs duty amount or making second instance decisions in tax proceedings. The competences of the tax administration bodies as far as forms of implementation of individual tasks are concerned are included in section V of the NFA Act (Art. 54 - Art. 143). It is thus needless to repeat the solutions, especially given that the aforementioned provisions are also not a closed catalog of the tasks of tax administration, which may also result from the provisions of other acts.

One of the tools for the implementation of the tasks of a consolidated National Fiscal Administration is using the existing audit procedure, i.e. the so-called customs and fiscal audit. The statutory assumptions referred to it as "hard audit", as opposed to the tax audit specified in Sec. VI of the TOA. These are two separate and independent control procedures, with tax audit possible to be performed by all first instance fiscal bodies as specified in Art. 13/1/1 of the TOA. The customs and fiscal audit, on the other hand, is a tool that enables fast response on the part of heads of customs and tax offices to fiscal offenses and transgressions.

When specifying the scope of the customs and fiscal audit, the legislator singled out, in Art. 54/1 of the NFA Act, the four major control areas. These pertain to compliance with the following laws: 1) tax law specified in Art. 3/2 of the TOA, 
2) customs legislation, 3) the Gambling Law, and 4) the Foreign Exchange Law. The scope of the customs and tax audit thus drafted is clear and introduces a great deal of flexibility in the area of planning and performance of audits. However, Art. $54 / 2$ of the NFA Act specifies additional instances for actions that are subject to the customs and tax audit, which cover, among others, the type of fuel in the tank of a vehicle, the manufacture and trade of game machines, road traffic, road transport, or export and import of goods subject to import restrictions or prohibitions. It should be thus concluded that the scope of the customs and tax audit is wider and does not overlap with the scope of the tax audit. Yet, in the case when the subject of the customs and tax audit is compliance with tax law, the scopes of both types of audit, as specified in Art. 54/1/1 of the NFA Act and Art. 281/2 of the TOA, clearly overlap. Hence, the criticized dual character of audit has in fact been retained. After all, both norms refer to the tax law regulation specified in Art. 3/2 of the TOA (Teszner, 2016: 209).

When indicating the powers of control of the National Fiscal Administration bodies, the mode of commencement of the customs and tax audit should be noted. According to Art. 62/1 and Art. 62/2 of the NFA Act, the audit is commenced ex officio, on the basis of relevant authorization. Commencement of an audit is no longer preceded by notifying the audited person on the initiation of a customs and tax audit proceeding related to them. Thus, tax administration bodies have been exempted from notifying the audited persons on a planned audit. Moreover, the possibility of performing the audit as a matter of urgency, presenting the service ID, in cases when non-compliance with regulations is suspected and the factual circumstances justify the immediate performance of a customs and tax audit, was foreseen.

The increased powers of the audit of NFA bodies are connected with the clear derogation from the obligation to each time establish the competent local body Authorized to perform the customs and tax audit. According to Art. 61 of the NFA Act, the head of the customs and tax office may perform customs and tax audits on the entire territory of Poland. This does not have to be the competent body for the audited person's domicile or the audited entity's seat, but rather the head of the customs and tax office that first commenced the audit. The consequence of this solution is not only an improvement of the performance of the customs and tax audit but also a consolidation of the competences of the head of the customs and tax office as far as the application of subsequent procedural solutions is concerned as, according to Art. 83/1 of the NFA Act, if a taxpayer fails to correct the tax return after being notified on the audit result and in accordance with the arrangements laid down in the document, then the completed custom and tax audit becomes a tax proceeding (Teszner, 2017: 26). The head of the customs and tax office that prepared 
the customs and tax audit result is thus the competent body Authorized to perform the tax proceedings and issue a decision, according to Art. 83/4 of the NFA Act. This solution was hitherto unheard-of in Polish procedures. What happens here is not a completion of a customs and tax audit and commencement of a separate tax proceeding, due to the fact that the stage of commencement of a tax proceeding is omitted. In this case, the legislator has ruled out the application of Art. 165 of the TOA, which regulates the rules for commencing a tax proceeding. Hence, a tax proceeding is initiated without its commencement but instead through transforming the already completed customs and tax audit.

The significantly broader scope of the customs and tax audit, in comparison with the solutions existing in the previous legal status, has a considerable impact on the place where audit activities are carried out. The provisions of the NFA Act foresee the possibility of performing the activities not only on the audited entity's or the auditing body's premises. Audits are also performed, for example, on public and internal access roads, in seaports and harbors, inland maritime waters, or marketplaces - also as permanent control - in places of manufacture and processing of excise goods and use of excise stamps, as well as in places where gambling is organized and held. Furthermore, in cases of audits performed by a uniformed officer equipped with personal identification markers, audit activities may be performed on border crossings, on the premises of customs and tax offices, or "at other places designated or approved by a relevant NFA body" (Act of NFA, Art. 62/13).

Within the framework of the customs and tax audit, the NFA has been granted broad powers, detailed in Art. 64 of the NFA Act. Some of these, such as the power of access and unrestricted movement on the premises of the audited entity's objects, the power of access to documents, examination, interrogation of the audited person and the witnesses, consultation with experts, securing the collected evidence, or sampling the goods, are similar to those granted to the auditor in other types of control. This provision, however, also foresees special audit powers that are granted exclusively to officers of the Customs and Tax Service. These include performing examination of goods, products, and means of transport, including with the use of technical equipment and police dogs, search of persons, escorting and safeguarding of goods, control of postal items, stopping vehicles and performing other tasks connected with road traffic control, stopping and controlling ships, or performing controls of the type of fuel used by sampling fuel from the vehicle's tank. The range of these prerogatives undoubtedly results from the procedures used by customs bodies and tax audit bodies. Within the framework of performing a customs and tax audit, it is also possible to assure, by way of a decision, the performance of tax and customs obligations over the audited person's assets (Act of NFA, Art. 80). 
Among the numerous powers of audit granted to the tax administration bodies, special attention should be paid to the right to demand from the audited person the files, records, books, and any other types of documents connected with the subject of the customs and tax audit, as well as to produce duplicates, copies, extracts, notes, and printouts, and documented retrieval of data in electronic form. This right also covers the records, books, and documents of any type connected with the subject of the audit for periods other than the period covered by the audit, provided that the period of storage specified in separate provisions has not expired (Act of NFA, Art. 64/3). This power, however, must not be understood as the intention on the part of the legislator for reference periods not covered by the subject of the audit to be subjected to control as part of an audit of a specific reference period.

Within the framework of the customs and tax audit, officers also exercise audit powers that make use of IT tools to a wider extent than previously. Interrogation of the audited person or a witness may be carried out remotely. Art. 76 of the NFA Act indicates that these actions may be performed via technical equipment that enables to carry them out remotely, with simultaneous transmission of sound and vision. The interview is recorded by means of an Audio Visual recording device and the record constitutes an annex to the report from the hearing, which is limited only to the most valid statements made by the participating persons.

Another example concerns the performance of an audit at the audited person's contractor, i.e. the so-called cross-check. This power results from Art. 79/1 and Art. 97/2 of the NFA Act. A significant difference, in comparison with the solutions included in the TOA, is the possibility for the head of the customs and tax office to submit to the audited person's contractor a request for transfer, by means electronic communication media or on an electronic data storage device, an extract from the tax records and accounting records recorded in electronic form. Exercising these powers is conditional on the audited person's contractor keeping tax books with the use of computer software.

\section{Expectations Towards the National Fiscal Administration}

One of the tasks of the National Fiscal Administration is to provide taxpayers and payers with services and support in the area of fulfilling their tax and customs obligations properly (Act of NFA, Art. 2/1/5). In accordance with the intention expressed in the preamble to the Act, ensuring the fulfillment of the obligations is to be modern and friendly. The willingness on the part of the legislator for the tax administration to withdraw in certain situations from the governmental authorities that it exercises in favor of performing taxpayer-dedicated services can be observed here. This approach is consistent with taxpayers' expectations, who wish to fulfill 
their tax obligations on a voluntary basis, with adequate support from the tax administration.

Scientific publications emphasize that, in addition to the traditional forms of operation based on administrative governance, there exist factors that diminish the role of governmental forms of tax administration actions in the process of fulfillment of tax obligations. Among these, the following are mentioned: checks, information campaigns, the tax return correction institution, the tax interpretation institution, or agreements on settlements on transaction prices (Pietrasz, et al.: 2013: 316). These are not, however, instruments that would ensure real support of entities in their fulfillment of tax obligations. The question could thus be raised whether the individual interest of honest taxpayers was also taken into consideration when the legislator was consolidating the tax administration, granting it new powers.

Providing taxpayers and payers with services and support in the area of fulfilling their tax and customs obligations properly is the task of the head of the tax office This body should undertake actions consisting in providing assistance in independent, correct, and voluntary fulfillment of tax obligations, implemented by the service center in the tax office (Act of NFA, Art. 28/1/5 and Art. 28/3) From the very start, an assumption was made that taxpayer services and support do not cover the preparation of applications, opinions, tax statements, or returns. This assumption is accurate as support provided to the taxpayer by the tax administration cannot fall within the activities covered by ${ }^{\text {tax }}$ advisory Art. 29/1 of the NFA Act foresees the following service and support activities:

1) accepting applications and returns, issuing certificates and explanations in the area of tax law, 2) providing guidance on how to complete tax statements and returns, 3) providing a computer workstation with access to the tax portal, 4) providing information on the contact data of the competent authorities together with their ranges of competences.

In the Author's opinion, the elements of service and support indicated above are insufficient. They mostly include the official duties of tax officials that they should be performing in any case, e.g. accepting applications or tax returns. What is lacking, therefore, are real support instruments implemented by offering IT services. An important instrument supporting taxpayers starting their business activity would be, for example, a taxpayer assistant in the initial stage of their activity; an introduction of this solution, however, was eventually rejected. An aspect that deserves a positive assessment, on the other hand, is the possibility to submit a tax return or obtain a certificate in any service center, irrespective of the territoriality of the head of the tax office. 


\section{Conclusions}

The organizational and legal solutions introduced in Poland in 2017, aimed at improving state revenue collection, resulted in establishing the National Tax Administration. In the systemic and organizational dimensions, the adopted solutions have introduced a change in the functioning of the tax administration and a strengthening of its supervision. In the procedural dimension, the administration has been equipped with new tools of control of liable entities.

A challenge faced by the National Fiscal Administration is an improved collection of revenue and duties through the introduction of effective audits, prosecution of the tax crime, and undertaking police actions. The expectations that honest taxpayers direct at the administration are a friendly approach to tax-paying entities and assistance and support in their fulfillment of tax obligations.

In the Author's opinion, the adopted solutions introduce unequal treatment of liable entities. The assistance and support tool offered to them fails to mitigate the newlyintroduced repressive legal instruments. The de facto retained duality of audit results in a serious risk of honest taxpayers and payers also being subjected to "hard audit". Doubtlessly, when introducing legal solutions in the public interest, the individual interest of taxpayers and entrepreneurs should be taken into consideration to a greater extent.

\section{References}

Boć, J.: Prawo administracyjne (Administrative law), Wrocław: Kolonia Limited, 2010.

Gajewski, D.J., Nowak-Far, A.: Krajowa Administracja Skarbowa - propozycja konsolidacji aparatu skarbowego a uszczelnienie systemu podatkowego (The National Fiscal Administration - a proposed consolidation of the fiscal services vs. closing the loopholes in the tax system), Analizy i Studia CASP (CASP Analyses and Studies) no. 2 (2016).

Gomułowicz, A.: Zasada sprawiedliwości podatkowej a prawodawstwo podatkowe (The principle of justice vs. tax legislation), in: Dzwonkowski, H. (ed.): W kręgu prawa podatkowego i finansów publicznych. Księga dedykowana profesorowi Cezaremu Kosikowskiemu w 40-lecie pracy naukowej (Within tax law and public finances. Book dedicated to Professor Cezary Kosikowski for the $40^{\text {th }}$ anniversary of his scientific work), Lublin: Wydawnictwo Uniwersytetu Marii Curie-Skłodowskiej, 2005.

Kosikowski, C.: Finanse publiczne w świetle Konstytucji RP oraz orzecznictwa Trybunału Konstytucyjnego (Public finances in the light of the Constitution of Poland and the Constitutional Tribunal case-law), Warszawa: Wydawnictwo Sejmowe, 2004.

Kosikowski, C.: Naprawa finansów publicznych w Polsce (Improvement of public finances in Poland), Bialystok: Temida 2, 2011. 
Kulicki, J.: Administracja danin publicznych w Polsce (Administration of public levies in Poland), Warszawa: Wydawnictwo Sejmowe, 2014.

Niewiadomski, Z.: Uwarunkowania kształtu współczesnej administracji publicznej (Conditions for the shape of the modern public administration), in: Hauser R., Niewiadomski, Z., Wróbel, A. (eds.): System prawa administracyjnego, T. 1: Instytucje prawa administracyjnego (The Administrative law system. Vol. 1: Administrative law institutions), Warszawa: C.H. Beck, 2010.

Pietrasz, P. (ed.): Siemieniako, J., Wróblewska, E.: Czynniki zmniejszające rolę władczych form działania administracji skarbowej w realizacji zobowiązań podatkowych (The factors that reduce the role of governmental forms of action of tax administration in the implementation of tax obligations), Warszawa-Bialystok: Aspra, 2013.

Smoleń, P. (ed.) et al.: System organów podatkowych w Polsce (The system of tax bodies in Poland), Warszawa: Oficyna Prawa Polskiego, 2009.

Teszner, K.: Administracja podatkowa i kontrola skarbowa w Polsce (Fiscal administration and fiscal audit in Poland), Warszawa: Wolters Kluwer, 2012.

Teszner, K.: Komentarz do art. 1 (Commentary to art. 1), in: Melezini, A., Teszner, K. (eds.): Krajowa Administracja Skarbowa. Komentarz (National Fiscal Administration. Commentary), Warszawa: Wolters Kluwer, 2018.

Teszner, K.: Modernizacja administracji niezespolonej w Polsce na przykładzie reform administracji skarbowej (Modernization of non-combined administration in Poland as exemplified by fiscal administration reforms), in: Sługocki, J. (ed.): Dziesięć lat polskich doświadczeń w Unii Europejskiej. Problemy prawnoadministracyjne, T. I (Ten years of Polish experience in the European Union. Legal and administrative issues Vol. 1), Wrocław: Presscom, 2014.

Teszner, K.: Przekształcenie kontroli celno-skarbowej w postępowanie podatkowe (Transforming the customs and tax audit into a tax proceeding), Procedury administracyjne i podatkowe (Administrative and tax procedures) no. 1 (2017).

Teszner, K.: Wpływ reformy administracji skarbowej na podatkowe postępowanie wyjaśniające (The impact of the tax administration reform on tax investigation), in: Dowgier, R., Popławski M. (eds.): Ordynacja podatkowa w praktyce. Zmiany w ogólnym prawie podatkowym (The Tax Ordinance Act in practice. Changes in general tax law), Bialystok: Temida 2, 2016.

Uzasadnienie projektu ustawy o Krajowej Administracji Skarbowej (The National Fiscal Administration Act substantiation document) no. 826, 2017. www.sejm.gov.pl.

Zimmermann J.: Prawo administracyjne (Administrative law), Warszawa: Wolters Kluwer Polska, 2016.

PL: Constitution of the Republic of Poland of 2 April 1997, as amended.

PL: Tax Ordinance Act of 29 August 1997, as amended.

PL: Act of 16 November 2016, on the National Fiscal Administration, as amended.

PL: Act of 16 November 2016, on Regulations implementing the Act on the National Fiscal Administration, as amended. 
PL: Constitutional Tribunal: K.28/98.

PL: Constitutional Tribunal judgment: K.12/94. 